\title{
Analysis of the Effects of Rivalry and Dynamism on the Firm's Competitive Position
}

\author{
Alexandre Teixeira Dias ${ }^{1}$ \\ alexandretdias@gmail.com | (D)0000-0002-0512-9829 \\ Eva Jaqueline Rolim Gonçalves de Sousa ${ }^{1}$ \\ eva.sousa@urbamais.com.br| (D)0000-0002-7069-0065 \\ Jersone Tasso Moreira Silva ${ }^{1}$ \\ tasso@fumec.br| (1D0000-0002-9977-9207 \\ Wendel Alex Castro Silva ${ }^{2}$ \\ wendel.silva@unihorizontes.br | (D)0000-0002-4974-8381
}

\begin{abstract}
The main objective of this study is to analyze the influences of dynamism and rivalry on the competitive position of US firms in the periods pre- and post-economic crisis of 2008, considering the role of firm size as a moderator. For this, data from firms operating in the manufacturing industry from 2001 to 2015 were used as a sample, analyzing the data through structural equation modeling. The model proposed in this study relates the constructs competitive position, dynamism and rivalry, using as a moderator the size of the firm. We found that the 2008 crisis influenced the environment in which the firms in the sample were inserted, causing a reduction in dynamism and rivalry. It was found that rivalry and firm size influenced competitive position, while dynamism, on the other hand, had little influence on competitive position. We also concluded that the dynamism of the industry has a direct influence on rivalry between firms.
\end{abstract}

\section{KEYWORDS}

Dynamism, Rivalry, Competitive Position, 2008 crisis, American firms

${ }^{1}$ Universidade Fumec,

Belo Horizonte, MG, Brasil

${ }^{2}$ Centro Universitário Unihorizontes, Belo Horizonte, MG, Brasil

Received: $12 / 06 / 2018$

Revised: 07/05/2019

Accepted: 10/21/2019

Published Online: 05/18/2020

DOI: http://dx.doi.org/10.15728/bbr.2020.17.4.1 


\section{INTRODUCTION}

Elahi (2013), assuming that the risk perspective of firms is in full evolution, states that the uncertainties which arise from the competitive environment have led to an increase of the managers exposure to risks, requiring the development of capacities that lead to obtaining competitive advantages.

According to Carvalho and Rossetto (2014), studies in strategy have often focused on the task of identifying the characteristics of a firm's operating environment, which has been considered one of the main influencers of the way firms act and the results obtained by them, from a perspective closely related to Evolutionary Theory, the first theme of the theoretical framework. Among such studies, the works of Li and Simerly (1998) and Simerly and Li (2000), which addressed the influences of industry dynamism, rivalry and munificence on firm performance, deserve to be highlighted, along with the research by Brito and Brito (2014), who analyzed the dynamics of competitive position (advantage, parity and disadvantage) and firm survival, and the work of Huang, Dyerson, Wu \& Harindranath (2015), who integrated the perspectives of the Industrial Organization and Resource-Based View by studying how temporary competitive advantages can be transformed into sustainable competitive advantages, highlighting the identification of the influence exerted by investment in the development of technological resources in obtaining sustainable competitive advantages.

In alignment with De-Carvalho and Dias (2016), who identified a positive quadratic effect between industry rivalry and firm profitability, and with Mello, Dias, Silva and Silva (2017), who addressed the effects exerted by the competitive environment and due to its competitive position in the performance of American firms in times of crisis, this research aims to measure and compare the influences exerted by the industry environment, in its rivalry and dynamism dimensions, on the competitive position of American firms in the pre- and post- 2008 global financial crisis, contributing to the theoretical field by proposing and testing hypotheses that may expand knowledge about the factors which determine the competitive position of firms, mainly due to consideration of periods of macroeconomic fluctuations that directly influenced the managers' strategic choices. The parameters of the proposed hypothetical model were estimated for each of the studied periods by modeling partial least squares (PLS) structural equations using the SmartPLS 3 software (Ringle, Wende, \& Becker, 2015).

\section{THEORETICAL FRAMEWORK}

\subsection{Evolutionary THeOry}

Based on fundamentals from economics, the Evolutionary Theory directs as "the primary focus on the dynamic processes by which firm behavioral patterns and market outcomes are jointly determined over time" (Nelson \& Winter, 1982, p. 18 ). According to the authors, the logical line of Evolutionary Theory is defined as such: at each point in time, the inputs and outputs of the processes are determined by the firms' operating capabilities and technologies, along with capital stock. From this, the prices of inputs and products are established with reference to the supply conditions presented by the suppliers and the demand conditions in the competitive environment, determining the profitability level of each firm (Nelson \& Winter, 1982). 
BBR

17

364

According to Rathe and Witt (2001), such aspects should be studied focusing on the dynamics of the environment, taking into account the adaptations generated as a reaction to changes originated from the environment and, consequently, not controlled by firms, and changes originating internally within firms.

Also according to Nelson and Winter (1982), firms' expansion and contraction rates are predominantly determined by their profitability, as investment decisions change the size of firms, which, in turn, sets new benchmarks in terms of input needs and production capacity. These adjustments, from a cyclical perspective, will determine the firm's price level and, in turn, its profitability. This evolutionary cycle also influences the competitive environment, as aggregate levels of input needs, production capacity, and price levels for industry will result in dynamic changes in both firms and the industry as a whole.

\subsection{Competitive Position}

According to Barney (1991) "firms gain sustainable competitive advantage by implementing strategies that exploit their internal strengths by responding to environmental opportunities while neutralizing their external threats and internal weaknesses." According to Porter (1992, p. 1), "Competitive strategy is the pursuit of a favorable competitive position in an industry, the fundamental arena where competition occurs. [...] it aims to establish a profitable and sustainable position against the forces that determine competition." As can be observed in the authors' statements, the competitive position of a firm, being it of competitive advantage, competitive disadvantage, or parity is directly influenced by the configuration of the competitive environment.

A firm's ability to increase its competitive advantage depends on its flexibility to change or develop new strategies. Firms also need to develop competitiveness factors such as cost, quality, delivery agility, and reliability best practices, tailoring their products and processes. Often aspects that seem obvious can be lost in the daily routines of firms, so it is important to create a favorable environment for positioning development. Competitiveness has become a deciding factor for survival. The firm needs to identify the factors that influence its competitiveness. Critical success factors are presented as items that need to be closely monitored for the firm to perform well and be competitive(Roman, Piana, Lozano, Mello, \& Erdmann, 2012; Castro Junior, Martins, Muiura, \& Silva, 2015).

It is not the calendar period that defines whether competitive advantage is sustainable or not, but instead competitors' inability to copy the strategy that guarantees such an advantage. This does not mean that this advantage will last forever, as it can change and the advantage be eliminated (Barney, 1991; O’Shannassy, 2008). Gaining competitive advantage is not simply the achievement of superior profitability, as it is usually treated in the literature, but is the firm being able to create above-average value from its competitors (Brito \& Brito, 2012).

Brito and Brito (2012) proposed a model that is a combined performance matrix, in which they found that most firms are in competitive parity, as can be seen in Figure 1. The study was conducted using Return On Asset (ROA) as a way of measuring profitability. To measure growth in market share, we used data on net sales over time, which were transformed into logarithms to enable the comparison of the compound rate over a five-year period. The period analyzed was between 1990 and 2009, divided into five-year intervals. The article concludes that growth is a relevant indicator of competitive advantage. Moreover, the position of competitive advantage is not so rare in a hyper-competitive scenario, as some authors argue (Brito \& Brito, 2012). 


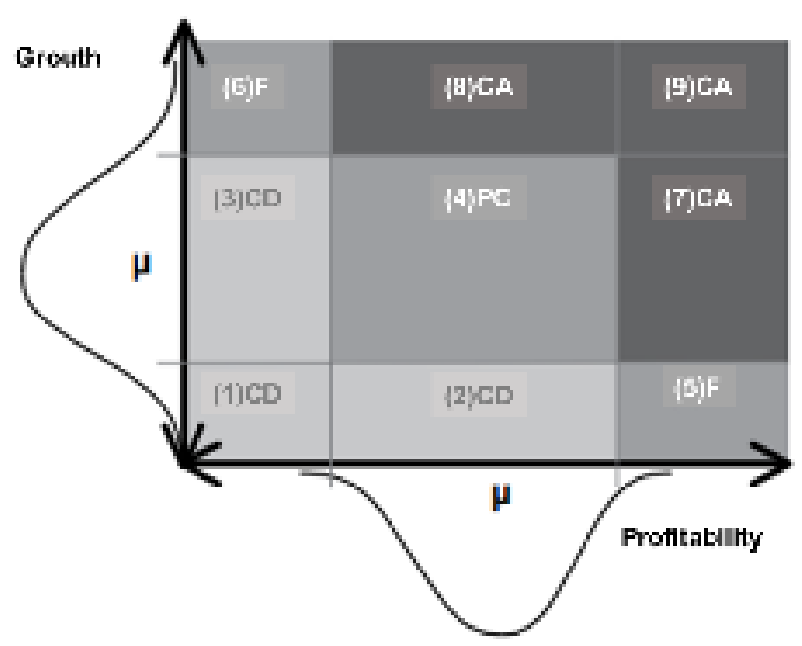

\begin{tabular}{|c|c|}
\hline Qun:Irurit & Classificatian \\
\hline 69 & Competitive Actvantage \\
\hline C8 & Competitive Adventage \\
\hline 07 & Competitive Advantage \\
\hline Q6 & Focus on Growth \\
\hline 65 & Foeus an Profitwbility \\
\hline 04 & Compotitive Parity \\
\hline CB & Compelitive Disadvantasy \\
\hline QR & Compentitha Disaduantage \\
\hline Q1 & Compofithv日 DIsadvantage \\
\hline
\end{tabular}

Figure 1. Combined Performance Matrix.

Source: Brito and Brito (2012).

\subsection{DYNAMISM}

Dynamism can be a source of advantage, while entrepreneurship can be a source of competitiveness. Firm dynamism is healthy for the economy, as healthy firms are always innovating, which makes the weaker ones also seek innovation (Brito \& Brito, 2012; Norris, 2014).

The dynamism construct can be understood as the variability in the various components of the competitive environment in which the firm is inserted. Components related to consumers, competitors, suppliers, social aspects, technology and industry regulation should be considered when measuring the dynamism of a competitive environment (Carvalho \& Rossetto, 2014, p. 71).

The studies by Li and Simerly (1998) present dynamism as a ratio between change and the degree of instability of factors within an environment. In this context, the dynamism of the industry is determined by several forces acting simultaneously, including the increase in the size and number of firms in the industry and the increase in the rate of technological transformation in the industry and the extent of their dispersion (Simerly \& $\mathrm{Li}, 2000$ ).

Nadkarni and Chen (2014) state that several studies show that the accumulated knowledge over the years, as well as the capabilities, make the most robust decisions about the right time to introduce new products to the market. They also explain the importance of real-time information as one of the key components that the firm needs in order to improvise and launch new products. The study concludes that firms that focus on the past in relation to new product launches excel in stable environments because they use past situations to understand the present. As to dynamic environments, those that focus on the future are those that can stand out, because the learning in these environments is transient (Nadkarni \& Chen, 2014). Developing the ability to process large amounts of data and assimilating it into its knowledge base, in order to create new knowledge, can help the firm to excel in competitive markets (Shi \& Wu, 2011), having in view that the increase in dynamism leads to reduced market share growth and revenue volume, affecting the firm's profitability (Yang \& Li, 2011). 
BBR

17

366

Based on the topics covered, we have the first research hypothesis:

- H1: The more dynamic the industry environment, the less favorable the firm's competitive position.

\subsection{RivalRY}

According to Hitt, Ireland, and Hoskisson (2003, p. 190), rivalry between firms begins "when two or more of them counteract in the pursuit of an advantageous market position. Competitive rivalry develops between them because one or more competitors feel pressured or see opportunities to improve their market positions."

Some factors influence the intense rivalry, among which we can highlight: large number of competitors in parity conditions, slow sector growth, high fixed costs, high exit barriers, and rivals with very diversified strategies. As to reducing the impact of rivalry, it can occur when competitors begin to focus on other segments that have faster growth or lower fixed costs (MasRuiz \& Ruiz-Moreno, 2011). In some cases, rival firms end up cooperating with the growth of other firms and, in other situations, they end up benefiting from their rival's growth by imitating the strategy of competitors (Coad \& Teruel 2012), conditions that lead to the modification of the competitive environment due to the strategic choices made by managers in terms of investments in advertising and innovation (Bhuyan \& McCafferty, 2013).

According to Mas-Ruiz and Ruiz-Moreno (2011, p. 57), "strategic group building captures the notion that the impact of rivalry on a firm's profitability depends on the location of its competitors for a relevant strategy." The authors studied the relationship between strategic group rivalry and its effects on firm performance and concluded that "although there is a direct link between the association of groups and firm profitability seems questionable, group structure can impact indirectly as it affects the conditions of rivalry” (Mas-Ruiz \& Ruiz-Moreno, 2011, p. 47).

As a consequence of firms' movements in the competitive environment, price may be influenced by rivalry and, consequently, also the level of profitability of the industry. In addition, prices tend to be higher in markets where there is less rivalry (Hamsa, Saab \& Rodrigues Filho, 2012). Research by Czarnitzki and Toole (2013, p. 26) shows that "strategic rivalry limits the firm's ability to delay ongoing projects and thus compensates for the influence of uncertainty on investment." Czarnitzki and Toole (2013) They also state that the specific effect of firm uncertainty on R\&D investments is less in markets where strategic rivalry is most intense.

Czarnitzki and Toole (2013, p. 26) demonstrate in their research findings that "firms in more concentrated markets or those with fewer direct competitors react less to uncertainty. This suggests that strategic rivalry stimulates innovation in markets with high levels of uncertainty," leading to increased asset investments that may result in increased market share and profitability. Thus, we have the following research hypotheses:

- H2: The greater the rivalry in the industry environment, the less favorable the firm's competitive position.

- Hз: The more dynamic the industry environment, the greater the rivalry. 


\subsection{Firm SizE}

According to Coase (1937), the firm has its origin in the competitive environment, based on

the decision makers' use of transaction costs as the basis for establishing formal relationships in their operating environment. Also, according to Coase (1937), firm growth can increase the costs of managing the firm's additional internal transactions to a point where they are equal to the costs that occur in the open market transaction, or the costs of organizing such transactions in a competitor.

When the firm's expansion reaches a point lower than open market selling costs and a point equal to the costs of organizing activities across the firm, a market transaction is created. Thus, the firm will tend to be higher when: (a) the costs of the organization are lower, even as the number of transactions increases; (b) there is less likelihood that firm managers and owners will comment on errors; and (c) the reduction in the supply price of factors of production for larger firms is greater (Coase, 1937).

Regarding the firm size approach, one should also take into account the work of Geanakopolos and Milgrom ( 1985 who state that firm size is established by reference to the comparison between the benefits of coordination and the cost of communication systems and information gathering. Another relevant perspective on the subject is Lucas's (1967) dynamic models on alignment costs as an explanation for the limits of growth rates.

Holmstrom and Tirole (1989) point out that traditional theories which address firm size are based on the role of technology capable of generating economies of scale, justifying the development of concentrated production, while marginal costs establish the optimal size of the firm. The authors add the considerations of Baumol et al. (1982) on the choice of the level of scale, the focus of Lucas (1978) and Kihlstrom and Laffont (1979) on reducing the allocation cost of management skills as a means of aligning firms and managers.

In order to act as efficient allocators of resources and efforts, it is necessary for firms to promote alignment between the organizational structure and market demands, which makes it possible to establish firms as structures in which relationships are controlled and adjusted according to prevailing interests (Williamson, 1998).

According to Starbuck (1965), quoted by Pfeffer (1972), the growth of organizations makes it possible to adjust to the environment, given that large companies develop better absorption capacity of mistaken actions and are better able to influence the environment. According to Damonpour (2010), the size of firms also allows them to diversify both in terms of terms and reduce their dependence on some product line that serves a specific industry, mainly through the development of production and product innovations. Damonpour (2010) and Mas-Ruiz and Ruiz-Moreno (2011) consider that firm size directly influences its strategic behavior and, consequently, its competitive position and responses to changes in the competitive environment. Thus, we have the proposition of the hypotheses:

- H4: The larger the firm, the more favorable its competitive position.

- H5: The effect of industry dynamism on competitive position is moderated by firm size.

- H6: The effect of industry rivalry on competitive position is moderated by firm size.

The research model was elaborated based on the hypotheses presented throughout this section, which are represented in Figure 2 by the arrows that connect the constructs. 


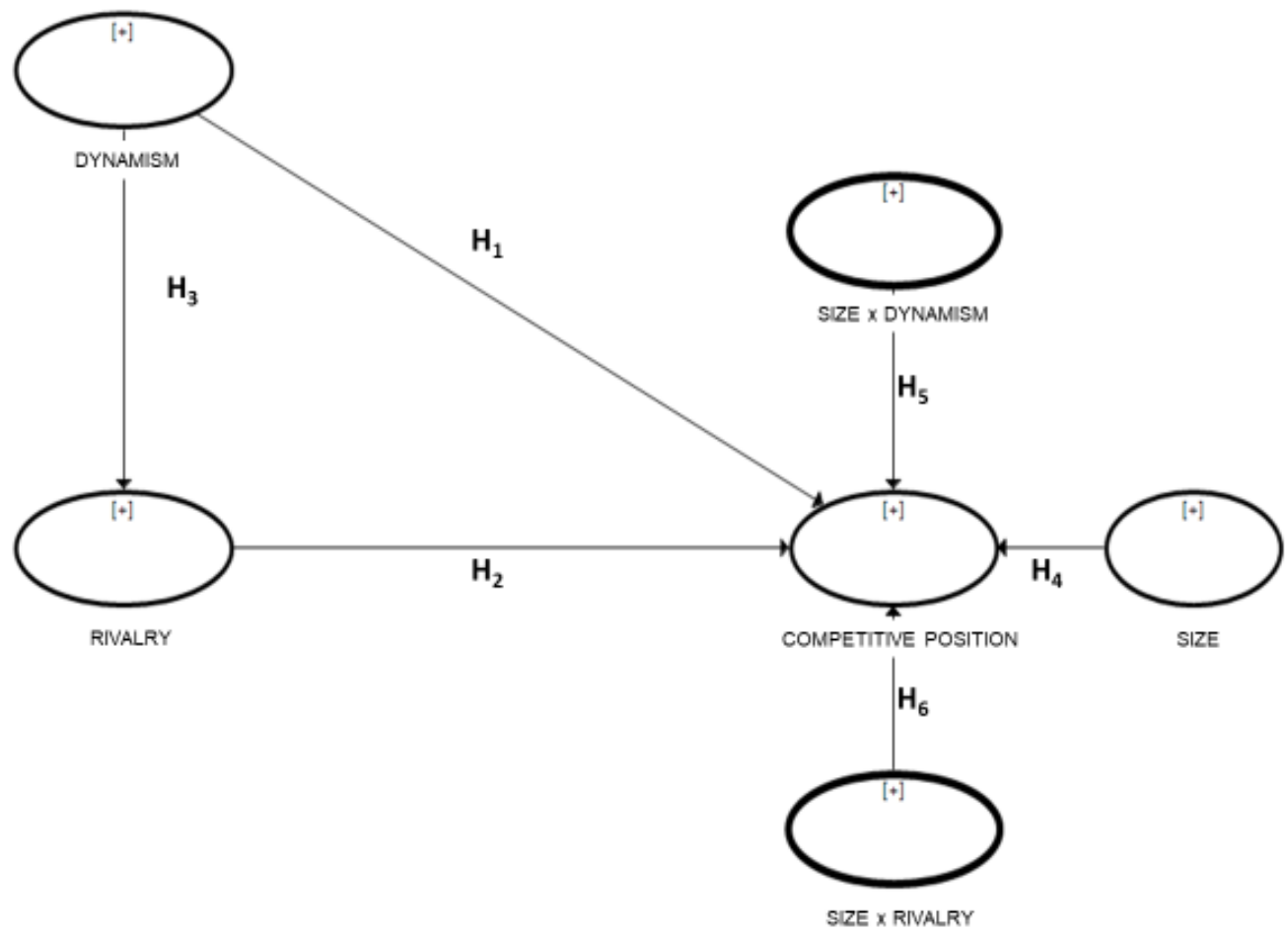

Figure 2. Structural model formulated according to the proposed hypotheses. Source: Prepared by the authors.

\section{METHODOLOGY}

The parameters of the proposed model were estimated using the Partial Least Squares (PLS) method, in order to predict and explain the variation of the competitive position of firms in the sample, in alignment with Henseler, Ringle and Sinkovics indications. (2009). Model parameters were estimated using SmartPLS 3 software (Ringle, Wende, \& Becker, 2015).

Chart 1 summarizes the operationalization of the model variables, which is explained below:

- Dynamism - calculated by dividing the standard error of the regression coefficient of firms' revenues over time by the average industry revenue to which they are linked, according to the procedure adopted by Li and Simerly (1998) and Simerly and Li (2000).

- Rivalry - calculated using the Shepherd G Index (1972), and calculated by subtracting the firm's market share from the Market Concentration Index (Herfindahl-Hirschman Index $\mathrm{HHI}$, which is the result of the sum of market shares of the firms that make up the industry. Market share was calculated by dividing the firm's revenues by the firm's total revenues in the industry. Such procedures were previously used by Cool, Röller and Leleux (1999) and by Bayar, Cornett, Erhemjamts, Leverty and Tehranian (2018).

- Competitive Position - Growth: calculated by changing the firm's market share (market share in the current period minus market share in the previous period and the result divided by market share in the previous period), according to the procedure adopted by Brito and Brito (2012). 
- Competitive Position - Profitability: calculated by dividing the firm's net income by its total assets, also in line with the procedure adopted by Brito and Brito (2012).

- Size: calculated by means of the neperian logarithmic transformation of total assets, calculated by the firm at the end of the fiscal period, according to the method adopted by Hansen and Wernerfelt (1989), Giachetti (2012) and De-Carvalho, Dias and Rossi (2018).

Chart 1

Operationalization of model variables.

\begin{tabular}{|c|c|c|}
\hline Category & Variable & Calculation form \\
\hline \multicolumn{3}{|c|}{ Environment } \\
\hline Rivalry & Shepherd's G Index (1972) & $\begin{array}{l}\text { Degree of industry concentration, calculated using the } \\
\text { Herfindahl-Hirschman Index - HHI, minus the firm's } \\
\text { market share. }\end{array}$ \\
\hline Dynamism & $\begin{array}{l}\text { Environmental dynamism index } \\
\text { according to Simerly and } \mathrm{Li}(2000)\end{array}$ & $\begin{array}{l}\text { Standard error of regression of industry sales figures in } \\
\text { relation to the year / average value of industry sales figures } \\
\text { in the year. }\end{array}$ \\
\hline \multicolumn{3}{|c|}{ Competitive position } \\
\hline Growth & $\Delta$ Firm’s Market Share & $\operatorname{~MKTSHARE~}_{\mathrm{T}}-$ MKTSHARE $\left._{(\mathrm{T}-1)}\right) /$ MKTSHARE $_{(\mathrm{T}-1)}$ \\
\hline Profitability & Return on Asset (ROA) & Net Income / Total Assets \\
\hline \multicolumn{3}{|r|}{ Firm size } \\
\hline Size & Total assets of the firm & Ln (ASSETS) \\
\hline
\end{tabular}

Source: Prepared by the authors.

\section{ANALYSIS OF RESULTS}

\subsection{Characterization of THE SAMple}

The sample studied in this research is composed of publicly traded US firms, active between 2001 and 2015, whose accounting information was made available on the Economática ${ }^{\circledR}$ database. This time interval was determined due to the availability of data for the firms that make up the sample, so that the sample size was not compromised and, mainly, because it covered the period of the economic crisis in the United States.

The samples worked were composed by 190 US firms operating in the manufacturing industry. Annual data was grouped into a pre-crisis period (2001 to 2007), the year of 2008, and a postcrisis period (2009 to 2015), constituting samples of 1,330, 190 and 1,330 cases, respectively. Therefore, the samples are significantly above the minimum number of 138 cases found for a test power of 0.95 , an effect size of 0.15 , five predictors and a $5 \%$ two-tailed significance test for determining a coefficient of determination statistically different from zero. The minimum sample size was calculated using the $G$ * Power 3.1.7 software (Faul, Erdefelder, Buchner, \& Lang, 2009) and with reference to the parameters established by Hair, Hult, Ringle and Sarstedt (2014).

Statistically significant differences were identified for the Dynamism averages between the pre-crisis period, the year of 2008, and the post-crisis period, as a result of Tukey's Multiple Comparison test (Table 1) indicating a greater degree of variability in revenue from firms studied in the period prior to the crisis of 2008 in relation to the subsequent periods, and, in the year 2008, 
BBR

17

370

in relation to the period after the crisis. Regarding the degree of Rivalry, the averages obtained for the pre-crisis period are higher than the averages obtained in 2008 and in the post-crisis period, while no statistically significant difference was identified between the averages obtained in 2008 and in the post-crisis period.

When considering the variables that are representative of competitive position, no statistically significant differences were identified in terms of Growth of firms (Table 1). Regarding the Profit, no statistically significant difference was identified between the averages obtained in the preand post-crisis periods, while a statistically significant difference was found between the 2008 average and the post-crisis average, indicating an increase in profitability of sample component firms. Regarding the Size of the firms, a statistically significant difference was found between the periods before and after the crisis, indicating a reduction over time, but with a stability in 2008, as indicated by the non-statistically significant difference found when comparing the average for that year and the periods before and after the crisis.

Table 1

Tukey's Multiple Comparison

\begin{tabular}{|c|c|c|c|c|}
\hline Variable & \multicolumn{2}{|c|}{ Compared periods } & Average difference & Significance \\
\hline \multirow{3}{*}{ Dynamism } & \multirow{2}{*}{ Before crisis } & After the crisis & 0.048 & 0.000 \\
\hline & & 2008 & 0.069 & 0.000 \\
\hline & After the crisis & 2008 & 0.021 & 0.021 \\
\hline \multirow{3}{*}{ Rivalry } & \multirow{2}{*}{ Before crisis } & After the crisis & 0.025 & 0.000 \\
\hline & & 2008 & 0.017 & 0.000 \\
\hline & After the crisis & 2008 & -0.008 & 0.180 \\
\hline \multirow{3}{*}{ Growth } & \multirow{2}{*}{ Before crisis } & After the crisis & 0.722 & 0.705 \\
\hline & & 2008 & 2.314 & 0.408 \\
\hline & After the crisis & 2008 & 1.592 & 0.654 \\
\hline \multirow{3}{*}{ Profitability } & \multirow{2}{*}{ Before crisis } & After the crisis & -0.577 & 0.240 \\
\hline & & 2008 & 2.715 & 0.000 \\
\hline & After the crisis & 2008 & 3.292 & 0.000 \\
\hline \multirow{3}{*}{ Size } & \multirow{2}{*}{ Before crisis } & After the crisis & -0.385 & 0.000 \\
\hline & & 2008 & -0.201 & 0.179 \\
\hline & After the crisis & 2008 & 0.184 & 0.237 \\
\hline
\end{tabular}

Source: Prepared by the authors.

Descriptive statistics regarding the indicators of the formative constructs of the research model are presented in Table 2. All sample validation tests and estimated parameters were developed for the complete sample and for the sample after outliers were excluded. The non-significant difference between the estimated parameters supported the choice because it considered only the sample without excluding cases in data processing. 
Table 2

Descriptive Statistics

\begin{tabular}{|c|c|c|c|c|c|}
\hline Period & Latent variable & Indicator & Sample size & Average & $\begin{array}{l}\text { Standard } \\
\text { deviation }\end{array}$ \\
\hline \multirow{5}{*}{ Before the Crisis } & Dynamism & Dynamism & 1,330 & 0.405 & 0.103 \\
\hline & Rivalry & Rivalry & 1,330 & 0.123 & 0.066 \\
\hline & \multirow{2}{*}{ Competitive position } & Growth & 1,330 & 3.411 & 25.061 \\
\hline & & Profitability & 1,330 & 4.666 & 9.082 \\
\hline & Control variable & Size & 1,330 & 15.234 & 1.471 \\
\hline \multirow{5}{*}{ Year 2008} & Dynamism & Dynamism & 190 & 0.357 & 0.103 \\
\hline & Rivalry & Rivalry & 190 & 0.098 & 0.052 \\
\hline & \multirow{2}{*}{ Competitive position } & Growth & 190 & 2.688 & 22.259 \\
\hline & & Profitability & 190 & 5.243 & 8.001 \\
\hline & Control variable & Size & 190 & 15.619 & 1.453 \\
\hline \multirow{5}{*}{ After the crisis } & Dynamism & Dynamism & 1,330 & 0.336 & 0.075 \\
\hline & Rivalry & Rivalry & 1,330 & 0.106 & 0.053 \\
\hline & \multirow{2}{*}{ Competitive position } & Growth & 1,330 & 1.097 & 18.043 \\
\hline & & Profitability & 1,330 & 1.951 & 15.853 \\
\hline & Control variable & Size & 1,330 & 15.435 & 1.458 \\
\hline
\end{tabular}

Source: Prepared by the authors.

\subsection{ANALYsis of THE MEASUREMENT MODEL}

The evaluation of the measurement model has, as its initial reference, the verification of the occurrence of collinearity between the indicators, as indicated by Hair et al. (2014). No Variance Inflation Factors (VIF) above the 5.000 limit were identified, as indicated by Hair et al. (2014) Table 3 -, result that indicates the inexistence of high level of redundancy of information shared by the formative indicators. Given that the Dynamism, Rivalry and Size constructs are represented by only one indicator, no results are presented for such constructs.

Still referring to Table 3, the weight of the Growth indicator is not statistically significant in the period before the crisis, as well as in 2008. As pointed out by Hair et al. (2014, p. 129), "indicators that do not present statistically significant weights should not be interpreted as indicating a poor ability to measure the respective constructs". According to Hair et al. (2014), the absolute contribution of each indicator of a formative construct should be evaluated by reference to the weight of each indicator, which should have a value above 0.500 . The Growth indicator has weights of $-0.541,-0.278$ and -0.401 for the pre-crisis period, for the year 2008 , and for the post-crisis period, respectively.

Despite the indication of withdrawal of the Growth indicator for the period before the crisis and for the year 2008, it was maintained due to the objective of testing the proposed model and not identifying the most appropriate model to measure the indicators for the sample in each period, besides maintaining the conceptual alignment with the theoretical bases that served as reference for the model proposition. Regarding the Lucrativity indicator, statistically significant weights above the reference point were found for the three periods analyzed. 
BBR

17

372

Table 3

Measurement model

\begin{tabular}{llcccccc}
\hline & & \multicolumn{9}{c}{ Periods } \\
\cline { 3 - 8 } Latent variable & \multirow{2}{*}{ Indicators } & \multicolumn{2}{c}{ Before crisis } & \multicolumn{2}{c}{ Year 2008 } & \multicolumn{2}{c}{ After the crisis } \\
\cline { 3 - 8 } & & Weight & VIF $^{2}$ & Weight & VIF & Weight & VIF $^{a}$ \\
\cline { 3 - 8 } & Growth & -0.541 & 1.003 & -0.278 & 1.017 & $-0.401^{* * *}$ & 1.020 \\
Competitive & Position & $0.869^{*}$ & 1.003 & $0.998^{* * *}$ & 1.017 & $0.974^{* * *}$ & 1.020 \\
\hline
\end{tabular}

${ }^{a}$ - Variance inflation factor - index for collinearity test, which should be below 5.000, as indicated by Hair et al. (2014).

${ }^{* * *} \mathrm{p}<0.010 ;{ }^{* *} \mathrm{p}<0.050 ;{ }^{*} \mathrm{p}<0.100$

The statistical significance of the indicators was verified by the bootstrapping technique, with 5,000 samples, with the option of not altering the signals.

Source: Prepared by the authors.

\subsection{ANALYSIS OF THE STRUCTURAL MODEL}

As for the measurement model, the first criterion used for the structural model evaluation is the verification of collinearity between the component constructs of the proposed model. As can be seen in Tables 4, 5 and 6, no collinearity was identified due to the determination of VIF values below the reference point - less than or equal to 5.000 - proposed by Hair et al. (2014).

As can be seen from Table 4, when considering the period prior to the crisis and its direct effects, industry dynamism exerts a statistically significant influence on Rivalry $(\beta=0.606$; $\mathrm{p}<0.010$ ) but does not exert a statistically significant influence on Competitive Position, a result also determined in the same period for the influence of Rivalry on Competitive Position. Still regarding the period before the crisis, a positive and statistically significant effect $(\beta=0.161$; $\mathrm{p}<0.100)$ of firm size in the Competitive Position was estimated. Regarding the moderating role of firm size in the effects of Dynamism and Rivalry on Competitive Position, no statistically significant effects were found in the pre-crisis period (Table 4).

Regarding 2008 (Table 4), a positive and statistically significant influence of Dynamism on Rivalry $(\beta=0.712 ; \mathrm{p}<0.010)$ and negative and statistically significant influence on Competitive Position $(\beta=-0.270 ; \mathrm{p}<0.050)$ were found. Also, during this period, there was a positive and statistically significant effect of the firm's Rivalry on Competitive Position $(\beta=0.209 ; p<0.100)$, as well as the Size on Competitive Position $(\beta=0.176 ; \mathrm{p}<0.050)$. As for the moderating effect of firm size, no statistically significant effect was found on the relationship between Dynamism and Competitive Position, while firm size negatively moderates the effect of Industry Rivalry on firm Competitive Position $(\beta=-0.271 ; \mathrm{p}<0.050)$ (Table 5).

When comparing the results of the estimation of path coefficients in the period before the crisis and in the year 2008, as shown in Table 4, a statistically significant difference was identified only for the effect of Dynamism on Competitive Position, which is more intense in 2008, as well as the moderating effect of firm size on the relationship between Industry Rivalry and Competitive Position - Table 5. 
Table 4

Structural model - Direct effects - Before the crisis $x$ Year 2008

\begin{tabular}{|c|c|c|c|c|c|c|}
\hline \multicolumn{2}{|c|}{ Latent variable } & \multicolumn{4}{|c|}{ Periods } & \multirow{2}{*}{$\begin{array}{c}\text { Difference } \\
\text { between periods }\end{array}$} \\
\hline Origin & Destiny & Before crisis & $\mathrm{VIF}^{\mathrm{a}}$ & Year 2008 & VIFa & \\
\hline \multirow{2}{*}{ Dynamism } & Rivalry & $0.606^{* * *}$ & 1.000 & $0.712^{* * *}$ & 1.000 & 0.105 \\
\hline & Competitive position & -0.051 & 1.687 & $-0.270^{* *}$ & 2.098 & $0.219^{* *}$ \\
\hline Rivalry & Competitive position & 0.057 & 1.625 & $0.209^{*}$ & 2,115 & 0.152 \\
\hline Size & Competitive position & $0.161 *$ & 1.099 & $0.176^{* *}$ & 1.084 & 0.015 \\
\hline
\end{tabular}

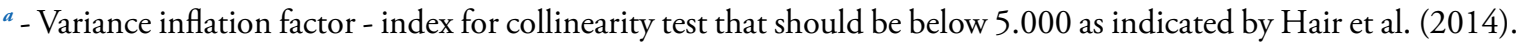
${ }^{* * *} \mathrm{p}<0.010{ }^{* *} \mathrm{p}<0.050{ }^{*} \mathrm{p}<0.100$

The statistical significance of the path coefficients was determined by the bootstrapping technique, with 5,000 samples, with the option of not changing the signals.

Source: Prepared by the authors.

Table 5

Structural Model - Moderating Effects - Before the crisis x Year 2008

\begin{tabular}{|c|c|c|c|c|c|c|}
\hline \multicolumn{2}{|c|}{ Latent variable } & \multicolumn{4}{|c|}{ Periods } & \multirow{2}{*}{$\begin{array}{c}\text { Difference } \\
\text { between periods }\end{array}$} \\
\hline Moderator & Moderate & Before crisis & $\mathrm{VIF}^{\mathrm{a}}$ & Year 2008 & $\mathrm{VIF}^{\mathrm{a}}$ & \\
\hline Size & Dynamism & -0.052 & 1,619 & 0.179 & 1.963 & 0.230 \\
\hline Size & Rivalry & -0.090 & 1,656 & $-0.271^{* *}$ & 2.084 & $0.181^{*}$ \\
\hline
\end{tabular}

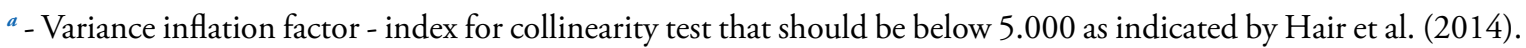
*** $\mathrm{p}<0.010$; ${ }^{* *} \mathrm{p}<0.050 ;{ }^{*} \mathrm{p}<0.100$

The statistical significance of the path coefficients was determined by the bootstrapping technique, with 5,000 samples, with the option of not changing the signals.

Source: Prepared by the authors.

As can be seen in Table 6, when considering the post-crisis period and the direct effects, Industry Dynamism exerts a positive and statistically significant influence on Rivalry $(\beta=0.690 ; \mathrm{p}$ $<0.010)$ and negative and statistically significant on Competitive Position $(\beta=-0.167 ; \mathrm{p}<0.010)$. Industry Rivalry has a positive effect on Competitive Position $(\beta=0.102 ; p<0.050)$, just as firm size positively influences Competitive Position $(\beta=0.147 ; \mathrm{p}<0.010)$. Regarding the moderating role of firm size in the effects of Dynamism and Rivalry on Competitive Position, statistically significant effects were found $(\beta=0.093 ; \mathrm{p}<0.050$ and $\beta=-0.165 ; \mathrm{p}<0.010$, respectively) in the post-crisis period - Table 7

Regarding the year 2008 (Table 6), there is a positive and statistically significant influence of Dynamism on Rivalry $(\beta=0.712 ; \mathrm{p}<0.010)$ and a negative and statistically significant influence on Competitive Position $(\beta=-0.270 ; \mathrm{p}<0.050)$. Also during this period, there was a positive and statistically significant effect of the firm's Rivalry on Competitive Position $(\beta=0.209 ; \mathrm{p}<0.100)$, as well as the size in the Competitive Position $(\beta=0.176 ; \mathrm{p}<0.050)$. As for the moderating effect of firm size, no statistically significant effect was found on the relationship between Dynamism and Competitive Position, while firm size negatively moderates the effect of Industry Rivalry on firm Competitive Position ( $\beta=-0.271 ; \mathrm{p}<0.050$ ) (Table 7 ).

When comparing the results of the estimation of path coefficients in the period after the crisis and in 2008, as presented in Table 6, no statistically significant difference was identified. 
BBR

17

374

Table 6

Structural model - Direct effects - After the crisis x Year 2008

\begin{tabular}{|c|c|c|c|c|c|c|}
\hline \multicolumn{2}{|c|}{ Latent variable } & \multicolumn{4}{|c|}{ Periods } & \multirow{2}{*}{$\begin{array}{c}\text { Difference } \\
\text { between periods }\end{array}$} \\
\hline Origin & Destiny & After the crisis & VIFa $^{a}$ & Year 2008 & VIF $^{a}$ & \\
\hline \multirow{2}{*}{ Dynamism } & Rivalry & $0.690^{* * *}$ & 1.000 & $0.712^{* * *}$ & 1.000 & -0.021 \\
\hline & Competitive position & $-0.167^{* * *}$ & 2.331 & $-0.270^{* *}$ & 2.098 & -0.103 \\
\hline Rivalry & Competitive position & $0.102^{* *}$ & 2.010 & $0.209 *$ & 2.115 & -0.107 \\
\hline Size & Competitive position & $0.147^{* * *}$ & 1.127 & $0.176^{* *}$ & 1.084 & -0.029 \\
\hline
\end{tabular}

a - Variance inflation factor - index for collinearity test that should be below 5.000 as indicated by Hair et al. (2014).

*** $\mathrm{p}<0.010 ;{ }^{* *} \mathrm{p}<0.050 ;{ }^{*} \mathrm{p}<0.100$

The statistical significance of the path coefficients was determined by the bootstrapping technique, with 5,000 samples, with the option of not changing the signals.

Source: Prepared by the authors.

Table 7

Structural Model - Moderating Effects - After the crisis x Year 2008

\begin{tabular}{|c|c|c|c|c|c|c|}
\hline \multicolumn{2}{|c|}{ Latent variable } & \multicolumn{4}{|c|}{ Periods } & \multirow{2}{*}{$\begin{array}{c}\text { Difference } \\
\text { between periods }\end{array}$} \\
\hline Moderator & Moderate & After the crisis & $\mathrm{VIF}^{\mathrm{a}}$ & Year 2008 & VIF $^{a}$ & \\
\hline Size & Dynamism & $0.093^{* *}$ & 2.101 & 0.179 & 1.963 & -0.086 \\
\hline Size & Rivalry & $-0.165^{* * *}$ & 1.887 & $-0.271^{* *}$ & 2.084 & -0.106 \\
\hline
\end{tabular}

a - Variance inflation factor - index for collinearity test that should be below 5.000 as indicated by Hair et al. (2014). *** $\mathrm{p}<0.010 ;{ }^{* *} \mathrm{p}<0.050 ;{ }^{*} \mathrm{p}<0.100$

The statistical significance of the path coefficients was determined by the bootstrapping technique, with 5,000 samples, with the option of not changing the signals.

Source: Prepared by the authors.

After identifying the adequacy of the proposed model to study the influences of Dynamism on industry Rivalry and these two - rivalry and dynamism - on the firm's Competitive Position, as well as the moderating effect of firm size on the effects of Dynamism and Rivalry on Competitive Position for the firms that make up the samples for the periods before and after the crisis and for 2008, the next step was the analysis of the proportion of variance of endogenous latent variables explained by the structural model, expressed by the adjusted determination coefficient $\left(\mathrm{R}_{\text {adj }}^{2}\right)$. According to Hair et al. (2014), an $\mathrm{R}_{\text {adj }}^{2}$ up to 0.250 represents reduced explanatory capacity, whereas $R_{\text {adj }}^{2}$ between 0.250 and 0.500 represents average explanatory capacity and $R_{\text {adj }}^{2}$ above 0.500 has great explanatory capacity.

In the case of this research, as can be seen in Table 8, the structural model was able to explain $36.70 \%\left(\mathrm{R}^{2}{ }_{\text {adj }}=0.367 ; \mathrm{p}<0.010\right), 47.60 \%\left(\mathrm{R}_{\text {adj }}^{2}=0.476 ; \mathrm{p}<0.010\right)$ and $50 ., 60 \%\left(\mathrm{R}^{2}{ }_{\text {adj }}=\right.$ 0.506 ; $\mathrm{p}<0.010)$ of the variance of the latent variable Rivalry pre-crisis, post-crisis and in 2008 respectively, representing average explanatory capacity in the first two and large in 2008.

Concerning the Competitive Position, a reduced explanatory capacity was found in the three periods: (a) 5.00\% $\left(\mathrm{R}^{2}{ }_{\text {adj }}=0.050 ; \mathrm{p}<0.010\right)$ in the period before the crisis; (b) $5.60 \%\left(\mathrm{R}_{\text {adj }}^{2}=\right.$ 0.056 ; $\mathrm{p}<0.010)$ in the post-crisis period; and (c) $11.50 \%\left(\mathrm{R}_{\text {adj }}^{2}=0.115\right.$; $\left.\mathrm{p}<0.050\right)$ in 2008 . These results have reduced explanatory capacity (Table 8$)$. 


\begin{tabular}{lccc}
\hline \multirow{2}{*}{ Latent variable } & \multicolumn{3}{c}{$\mathrm{R}_{\text {adj }}$} \\
\cline { 2 - 4 } & Periods & Periods \\
\cline { 2 - 4 } & $0.367^{* * *}$ & $0.476^{* * *}$ & Year 2008 \\
\hline Rivalry & $0.050^{* * *}$ & $0.056^{* * *}$ & $0.506^{* * *}$ \\
Competitive position & & $0.115^{* *}$ \\
\hline
\end{tabular}

${ }^{* * *} \mathrm{p}<0,010 ;{ }^{* *} \mathrm{p}<0,050 ;{ }^{*} \mathrm{p}<0,100$

Source: Prepared by the authors.

Hair et al. (2014) indicates, as a complement to the analysis of path coefficients and determination coefficients, the analysis of the contribution level of each exogenous construct to explain the variance of endogenous constructs, performed by evaluating the effect size $\left(\mathrm{f}^{2}\right)$. As suggested by the authors, effects between 0.020 and 0.150 are considered small; between 0.150 and 0.350 are considered average; and above 0.350 are considered large. Effects below 0.020 may be considered insignificant.

According to the data presented in Table 9, Dynamism makes a great contribution to the explanation of the variance of the Rivalry construct in the three periods under analysis, and a small contribution to the explanation of the variance of the Competitive Position construct in 2008. It was also a found small contribution of Rivalry to explain the variance of the Competitive Position construct in 2008, a result similar to that found for contribution of the moderating effect of size on the influence of Rivalry on Competitive Position.

Also according to Table 9, the size of the firm makes a small contribution to the explanation of the variance of the Competitive Position construct in the three periods analyzed.

Table 9

Effect Size - $f^{2}$

\begin{tabular}{lcccc}
\hline & Latent variable & \multicolumn{3}{c}{ Periods } \\
\hline Origin & Destiny & Before crisis & After the crisis & Year 2008 \\
\hline \multirow{2}{*}{ Dynamism } & Rivalry & $0.581 \dagger$ & $0.909 \dagger$ & $1.025 \dagger$ \\
& Competitive position & 0.002 & 0.013 & $0.039 £$ \\
Rivalry & Competitive position & 0.002 & 0.006 & $0.023 £$ \\
Size & Competitive position & $0.025 £$ & $0.020 £$ & $0.032 £$ \\
Size x dynamism & Competitive position & 0.002 & 0.005 & 0.012 \\
Size x rivalry & Competitive position & 0.005 & 0.014 & $0.037 £$ \\
\hline
\end{tabular}

$£$ - small effect; $\mu$ - mean effect; $\dagger$ - large effect

Source: Prepared by the authors.

\subsection{ANALYSIS OF RESEARCH HYPOTHESES AND DISCUSSION OF RESULTS}

This subsection presents the analysis of the research hypotheses and the discussion of the results, considering the validity of the proposed model and the statistical significance of the structural model path coefficients.

The first research hypothesis, $\mathbf{H}_{1}$ - The more dynamic the industry environment, the less favorable the firm's competitive position, was not rejected for the three periods considered in the 
BBR

17

376

survey due to the negative sign of the path coefficient and the positive weight of the Profitability indicator, despite the negative sign of the weight of the Growth indicator. This result points to a trend of lower Growth and higher Profitability, the more dynamic the industry environment is.

As for the second hypothesis, $\mathbf{H}_{2}$ - The greater the rivalry in the industry environment, the less favorable the firm's competitive position, its rejection in the pre-crisis period is due to the non-statistical significance of the estimated path coefficient. As for the periods after the crisis and in 2008, its rejection is due to the positive sign of the estimated path coefficient, which is statistically significant.

The third hypothesis, $\mathbf{H}_{3}$ - The more dynamic the industry environment, the greater the rivalry, was not rejected in the three periods under analysis, in view of the estimation of positive and statistically significant signal path coefficients for the effects of Dynamism on Rivalry. The positive and statistically significant signal path coefficient estimated for the effect of firm size on the Competitive Position, in the three periods under analysis, leads to the non-rejection of the fourth research hypothesis, $\mathbf{H}_{4}$ - The larger the firm, the more favorable its competitive position.

The fifth research hypothesis, $\mathbf{H}_{\mathbf{5}}$ - The effect of industry dynamism on competitive position is moderated by firm size, was rejected for the period before the crisis and for 2008 due to the non-statistical significance of the estimated path coefficients. As for the period after the crisis, the statistical significance of the path coefficient guarantees the non-rejection of the hypothesis under analysis.

The sixth hypothesis, $\mathbf{H}_{\mathbf{6}}$ - The effect of industry rivalry on competitive position is moderated by firm size, was also rejected for the pre-crisis period because of the non-statistical significance of the estimated path coefficient. For the year 2008 and the post-crisis period, the hypothesis was not rejected, given the statistical significance of the estimated parameter.

The results point to different intensities of the effects of dynamism and rivalry on the firm's competitive position in the three periods analyzed, pointing to the relevant role of the indirectly identified macroeconomic context in the strategic direction of firms. After extensive bibliographic survey, no studies were found that addressed the relationships between the constructs that integrate the research model, making it impossible to compare the estimated results with the results of other research.

\section{FINAL CONSIDERATIONS}

In order to increase the knowledge base on environmental factors (rivalry and dynamism) and their influence on the competitive position of firms, this paper sought to answer the following question: "What are the influences of rivalry and dynamism of the competitive environment on competitive position of the firm?" For this, a model was proposed relating the constructs, using as a moderator the size of the firm. The Economática ${ }^{\circledR}$ database, containing information from publicly traded US firms from 2001 to 2015, was used to identify pre and post-2008 financial crisis variations, with 2008 being considered separately.

Through the analyzes, it was identified that there were variations in the dynamism of the industry, when considering the periods before and after the crisis of 2008. Analyzing the dynamism of the industry as a factor that influences the firm's competitive position, a trend towards lower growth and higher profitability was observed as the environment dynamism increased, indicating a tendency to seek remuneration for investments made in assets, to the detriment of expanding market share. Regarding the effects of dynamism on industry rivalry, effects of similar intensities were estimated in the periods under analysis, indicating that the more dynamic the environment, 
the greater the rivalry in the industry, as a consequence of the pursuit of expansion of market share by firms in the sample.

By measuring the degree of rivalry, it was found that the averages of the pre-crisis period were higher than 2008, but no statistically significant differences were identified between 2008 and the post-crisis period. Thus, it is possible to see that the crisis influenced the environment in which the firms studied were inserted, causing a reduction in rivalry. It was also confirmed that the greater the rivalry, the more favorable the firm's competitive position was in 2008 and beyond. However, rivalry has no influence on the competitive position in the period prior to 2008. These results point to the tendency of the firms in the sample to respond to the increase in rivalry by seeking to expand market share and, consequently, with the increase in revenues, leading to increased profitability, provided that costs and expenses are maintained.

A noteworthy point is the moderating role of firm size in relation to the effects of dynamism and rivalry on competitive position and its direct effect on competitive position. The results indicate similar effects of size intensities on competitive position in the three periods, whereas firm size does not moderate the dynamism effects in the pre-crisis period, nor does it moderate the dynamism effects in the year 2008, but acts as a reducer of the effects of dynamism on the competitive position in the post-crisis period. The latter result points to a greater responsiveness to changes in the environment by larger firms.

The moderation exerted by the size of the effects of rivalry on competitive position in 2008 and in the post-crisis period indicates a greater ability for larger firms to cope with competitors' actions.

Regarding the competitive position of firms in the analyzed periods, there were, in general, no major variations in their competitive positions when comparing the periods before and after the crisis. Most firms were in a competitive parity position for the three periods studied, and the variation between those in a competitive advantage and competitive disadvantage position was low.

The study contributes to increasing the knowledge about the constructs, as well as the understanding of the relationship between them. It is also a source of information regarding the influence of the 2008 financial crisis on the dynamism of the environment, on rivalry between firms and on the competitive position of US firms. 


\section{REFERENCES}

Barney, J. (1991). Firm resources and sustained competitive advantage. Journal of Management, 17(1), 99-120.

Baumol, W., Panzer, J., \& Willig, R. (1982). Contestable markets and the theory of industry structure. New York: Harcourt Brace Jovanovich.

Bayar, T., Cornet, M. M., Erhemjamts, O., Leverty, T., \& Tehranian, H. (2018). An examination of the relation between strategic interaction among industry firms and firm performance. Journal of Banking and Finance, 87, 248-263. https://doi.org/10.1016/j.jbankfin.2017.10.009

Bhuyan, S., \& McCafferty, M. (2013). U. S. Brewing Industry profitability: a simultaneous determination of Structure, Conduct and Performance. Journal of Agricultural \& Food Industrial Organization, 11(1), 139-150.

Brito, R. P., \& Brito, L. A. L. (2012). Vantagem competitiva, criação de valor e seus efeitos sobre o desempenho. Revista de Administração de Empresas, 52(1), 70-84.

Brito, R. P., \& Brito, L. A. L. (2014). Dynamics of competition and survival. Brazilian Administration Review, 11(1), 64-85.

Carvalho, C. E., \& Rossetto, C. R. (2014). Proposição e teste de uma escala de dinamismo, complexidade e munificência ambiental. Revista Ibero-Americana de Estratégia, 3(4), 60-73.

Castro Junior, D. F. L. do, Martins, E. S., Muiura, M. N., \& Silva, M. P. P. (2015). O processo de formulação de estratégias e os recursos intangíveis da empresa: reflexôes teóricas sobre esta relação. Revista Capital Cientifico - Eletrônica, 13(1). https://revistas.unicentro.br/index.php/ capitalcientifico/article/view/2870/2543

Coad, A., \& Teruel, M. (2012, June 28). Inter-firm rivalry and firm growth: is there any evidence of direct competition between firms? Industrial and Corporate Change, 22(2), 397-425. https://doi. org/10.1093/icc/dts018 Advance Access Published.

Coase, R. (1937). The Nature of the Firm. Economica, 4, 386-405.

Cool, K., Röller, L-H, \& Leleux, B. (1999). The relative impact of actual and potential rivalry on firm profitability in the pharmaceutical industry. Strategic Management Journal, 20, 1-14.

Czarnitzk, D., \& Toole, A. A. (2013). The R\&D Investment-Uncertainty Relationship: Do strategic rivalry and firm size matter? Managerial and Decision Economics, 34(1), 15-28.

Damonpour, F. (2010). An Integration of Research Findings of Effects of Firm Size and Market Competition on Product and Process Innovations. British Journal of Management, 21, 996-1010. https://doi.org/10.1111/j.1467-8551.2009.00628.x

De-Carvalho, J. P., \& Dias, A. T. (2016). Influências não lineares da indústria no desempenho da firma. Revista de Administração de Empresas, 56(5), 503-517. https://doi.org/10.1590/S0034759020160505

De-Carvalho, J. P., Dias, A. T., \& Rossi, F. S. M. (2018). Efeitos da munificência no desempenho da firma. Revista Ciências Administrativas, 24(1), 1-12. https://doi.org/10.5020/2318-0722.2018.6041

Elahi, E. (2013). Risk management: the next source of competitive advantage. Foresight, 15(2), 117 131. https://doi.org/10.1108/14636681311321121

Faul, F., Erdfelder, E., Buchner, A., \& Lang, A. G. (2009). Statistical power analyses using G*Power 3.1: Tests for correlation and regression analyses. Behavior Research Methods, 41(4), 1149-1160. https://doi.org/10.3758/brm.41.4.1149 
Giachetti, C. (2012). A resource-based perspective on the relationship between service diversification and firm performance: evidence from Italian facility management firms. Journal of Business Economics and Management, 13(3), 567-585.

Geanakopolos, J. \& Milgrom, P. (1985). A theory of hierarchies based on limited managerial attention. Cowles Foundation paper no. 775, Yale University.

Hair, J. F., Hult, T. M., Ringle, C. M., \& Sarstedt, M. (2014). A primer on Partial Least Squares Structural Equations Modeling (PLS-SEM). Los Angeles: SAGE.

Hansen, G. S., \& Wernerfelt, B. (1989). Determinants of firm performance: the relative importance of economic and organizational factors. Strategic Management Journal, 10(5), 399-411.

Henseler, J., Ringle, C. M., Sinkovics, R. R. (2009). The use of partial least squares path modeling in International Marketing. Advances in International Marketing, 20, 277-319.

Hitt, A. M., Ireland, R. D., \& Hoskisson, R. E. (2003). Administração Estratégica. Tradução de José Carlos Barbosa dos Santos e Luiz Antônio Pedroso Rafael. São Paulo: Pioneira Thomson Learning.

Holmstrom, B. R., \& Tirole, J. (1989). The theory of the firm. In: Schmalensee, R., \& Willig, R. D.. Handbook of Industrial Organization - Volume 1. Elsevier, 1989.

Huang, K.-F., Dyerson, R., Wu, L.-Y. \& Harindranath, G. (2015). From Temporary Competitive Advantage to Sustainable Competitive Advantage. British Journal of Management, 26(4), 617-636. https://doi.org/10.1111/1467-8551.12104.

Li, M., \& Simerly, R. L. (1998). The moderating effect of environmental dynamism on the ownership and performance relationship. Strategic Management Journal, 19, 169-179.

Lucas, R. (1978). On the size distribution of business firms. Bell Journal of Economics, 9, 508-523.

Kihlstrom, R., \& Laffont, J.-J. (1979). A general equilibrium entrepreneurial theory of the firm based on risk aversion. Journal of Political Economy, 87, 719-748.

Mas-Ruiz, F., \& Ruiz-Moreno, F. (2011). Rivalry within strategic groups and consequences for performance: the firm-size effects. Strategic Management Journal, 32, 1286-1308. https://doi. org/10.1002/smj.936

Mello, J. R. C. A., Dias, A. T., Silva, J. T. M., \& Silva, W. A. C. (2017). Efeitos das flutuações da crise econômica de 2008 na posição competitiva e no desempenho de firmas americanas listadas em bolsa. In: Anais, VIII Encontro de Estudos em Estratégia - 3Es, Curitiba: Anpad. http:// www.anpad.org.br/ -anpad/eventos.php?cod_evento=3\&cod_evento_edicao=87\&cod_edicao_ subsecao $=1424 \&$ cod_edicao_trabalho=22477.

Nadkarni, S, \& Chen, J. (2014). Bridging yesterday, today, and tomorrow: CEO temporal focus, environmental dynamism, and rate of new product introduction. Academy of Management Journal, 57(6), 1810-1833.

Nelson, R. R., \& Winter, S. G. (1982). An evolutionary theory of economic change. Harvard University Press, 1982.

Norris, A. (2014). Business dynamism: is it really declining? U.S Bureau of Labor Statistics. Monthly Labor Review, p. 1-3.

O’Shannassy, T. (2008). Sustainable competitive advantage or temporary competitive advantage: Improving understanding of an important strategy construct, Journal of Strategy and Management, 2, 168-180. https://doi.org/10.1108/17554250810926357 
BBR

17

Pfeffer, J. (1972). Size and composition of corporate boards of directors: the organization and its environment. Administrative Science Quarterly, 17, 218-228.

Porter, M. E. (1992). Vantagem competitiva: Criando e sustentando um desempenho superior. Tradução de Elizabth Maria de Pinto Braga. Rio de Janeiro: Campus.

Ringle, C. M., Wende, S., \& Becker, J.-M. (2015). SmartPLS 3. Boenningstedt: SmartPLS GmbH. http://www.smartpls.com

Rathe, K., \& Witt, U. (2001). The nature of the firm - static versus developmental interpretations. Journal of Management and Governance, 5, 331-351.

Roman, J. D., Piana, J., Lozano, M. A. S. P. L., Mello, N. R., \& Erdmann, R. H. (2012). Fatores de competitividade organizacional. Brazilian Business Review, 9(1), 27-46.

Shepherd, W. G. (1972). Elements of market structure: An inter-industry analysis. Southern Economic Journal, 38 (4), 531-537.

Shi, L. H., \& Wu, F. (2011). Dealing with market dynamism: The role of reconfiguration in global account management. Management International Review, 51, 635-663.

Simerly, R. L., \& Li, M. (2000). Environmental dynamism, capital structure and performance: a theoretical integration and an empirical test. Strategic Management Journal, 21, 31-49.

Starbuck, W. H. (1965). Organizational growth and development. In: March, J. G.; Handbook of Organizations. Chicago: Rand McNally, p. 451-533.

Williamson, O. E. (1998). The institutions of governance. American Economic Review, 88(2), 75-79.

Yang, T.-T.; \& Li, C.-R. (2011). Competence exploration and exploitation in new product development: The moderating effects of environmental dynamism and competitiveness. Management Decision, 49(9), 1444-1470. https://doi.org/10.1108/00251741111173934

\section{AUTHOR'S CONTRIBUTION}

ATD - acted in coordinating the research project, supervising the analyzes, processing and analyzing the data, discussing the results and preparing the final considerations;

EJRGS - worked on the development of the theoretical framework, data analysis and preparation of final considerations; JTMS - worked on the introduction development, data analysis and final considerations;

WACS - worked on the development of the introduction, the discussion of the results and the elaboration of the final considerations.

\section{CONFLICTS OF INTEREST}

The authors declare that there are no conflicts of interest regarding the research developed. 